\title{
Identification and Characterization of Botrytis Blossom Blight of Japanese Plums Caused by Botrytis cinerea and B. prunorum sp. nov. in Chile
}

\author{
Enrique E. Ferrada, Bernardo A. Latorre, Juan P. Zoffoli, and Antonio Castillo
}

First, second, and third authors: Facultad de Agronomía e Ingeniería Forestal, Pontificia Universidad Católica de Chile, Vicuña Mackenna 4860, Santiago, Chile; and fourth author: Departamento de Biología, Facultad de Química y Biología, Universidad de Santiago de Chile, Alameda 3363, Santiago.

Accepted for publication 12 October 2015.

\begin{abstract}
Ferrada, E. E., Latorre, B. A., Zoffoli, J. P., and Castillo, A. 2016. Identification and characterization of Botrytis blossom blight of Japanese plums caused by Botrytis cinerea and B. prunorum sp. nov. in Chile. Phytopathology 106:155-165.

Blossom blight is a destructive disease of plums (Prunus salicina) when humid and temperate weather conditions occur in Chile. Disease incidence ranging from 4 to $53 \%$ has been observed. Symptoms include light brown petal necrosis, starting as light brown mottles or V-shaped necrosis at the margins of the petals, progressing to the stamen and pistils. In this study, the etiology of blossom blight of plums was determined. High- and low-sporulating isolates of Botrytis were obtained consistently from blighted blossoms and apparently healthy flowers of plums. Based on colony morphology, conidial production and molecular phylogenetic analysis, these high- and low-sporulating isolates were identified as $B$. cinerea and B. prunorum sp. nov., respectively. Phylogenetic analysis of the genes glyceraldehyde 3-phosphate dehydrogenase $(G 3 P D H)$, heat-

shock protein 60 (HSP60), and DNA-dependent RNA polymerase subunit II (RPB2) grouped B. prunorum isolates in a single cluster, distantly from $B$. cinerea and other Botrytis species. The phylogenetic analysis of necrosis and ethylene-inducing protein (NEP1 and NEP2) genes corroborated these results. Analysis of the internal transcribed spacer region and large-subunit (26S) ribosomal DNA and detection of Boty and Flipper transposable elements, were not useful to differentiate between these Botrytis species. Both species were pathogenic on plum flowers and the fruit of plums, apples, and kiwifruits. However, B. prunorum was less virulent than $B$. cinerea. These pathogens were re-isolated from inoculated and diseased tissues; thus, Koch's postulates were fulfilled, confirming its role in blossom blight of plums. B. cinerea was predominant, suggesting that $B$. prunorum may play a secondary role in the epidemiology of blossom blight in plums in Chile. This study clearly demonstrated that the etiology of blossom blight of plums is caused by $B$. cinerea and $B$. prunorum, which constitute a species complex living in sympatry on plums and possibly on other stone fruit trees.
\end{abstract}

The Japanese plum (Prunus salicina Lindl.) is a very important stone fruit species in Central Chile, currently with over 6,000 ha primarily destined for export as fresh fruit to markets in the United States, Europe, and Asia (www.odepa.cl). Blossom blight has become a very common disease and is often confused with the early stages of the brown rot caused by Monilinia fructicola (Winter) Honey and/or M. laxa (Aderh. and Ruhl) Honey. However, Botrytis spp. have been found to be associated with this disease (Ferrada et al. 2014).

Botrytis blossom blight occurs when cool and wet weather conditions prevail during flowering. The symptoms are characterized by a light brown necrosis of the petals that may affect the entire flowers, which remain attached to the twigs for some time. As it has been described on other hosts, the disease often progresses from fading petals into the rest of the inflorescence (Droby and Lichter 2004). Eventually, gray mold appears on the necrotic tissues under highly humid conditions in the field, and the same symptoms can also be induced in humid chambers under laboratory conditions. A similar disease, green fruit rot (blossom rot or jacket rot) caused by B. cinerea, was previously described (Flint 1995). However, the overall colony morphology of the pathogen(s) suggests that more than one species of Botrytis are associated with blossom blight of Japanese plums in Chile.

The genus Botrytis currently comprises 301 valid species (www. mycobank.org). Most of these species have been identified based on the morphological features and host specificity, but DNA-based

Corresponding author: B. A. Latorre; E-mail address: blatorre@uc.cl

http://dx.doi.org/10.1094/PHYTO-06-15-0143-R

(C) 2016 The American Phytopathological Society molecular characterization has recently been used to delimit newer Botrytis species. Phylogenetic analyses using the sequences of the nuclear genes glyceraldehyde-3-phosphate dehydrogenase $(G 3 P D H)$, heat-shock protein 60 (HSP60), and DNA-dependent RNA polymerase subunit II (RPB2) have been used to corroborate the identification of Botrytis species (Li et al. 2012; Lorenzini and Zapparoli 2014; Zhang et al. 2010a,b; Zhou et al. 2014). Similarly, phylogenetic analyses of the partial sequences of the beta-tubulin gene and G3PDH supported the identification of B. mali Ruehle (O'Gorman et al. 2008). Furthermore, the necrosis and ethyleneinducing protein (NEP) genes 1 and 2 (Staats et al. 2007) could be used to design specific primers to identify some species of Botrytis (Grant-Downton et al. 2014; Li et al. 2012; Lorenzini and Zapparoli 2014; Mirzaei et al. 2008; Staats et al. 2007).

A survey conducted in Central Chile from 2012 to 2014 showed that $B$. cinerea and an unidentified Botrytis sp. 1 were associated with blossom blight symptoms on Japanese plums (Ferrada et al. 2014, 2015). The colony morphology and scarce conidial production distinguished Botrytis sp. 1 from B. cinerea. Therefore, the aim of this study was to characterize the Botrytis blossom blight of Japanese plums and to identify Botrytis sp. 1 by cultural and morphological characteristics and phylogenetic analysis using the sequences of the nuclear genes mentioned above. The pathogenicity of isolates of B. cinerea and Botrytis sp. 1 were compared and the relative importance of these species was estimated.

\section{MATERIALS AND METHODS}

Sampling locations and fungal isolation. Diseased and apparently healthy flowers were collected during full bloom 
(August to September ) from six commercial orchards of Japanese plums in six geographic localities in Central Chile $\left(33^{\circ} 29^{\prime}\right.$ to $34^{\circ} 39^{\prime}$ Lat. S.) during the 2012, 2013, and 2014 growing seasons. In each orchard, 100 diseased and 100 apparently healthy flowers were collected from at least 10 trees. Flower samples were transported to the laboratory in plastic boxes. Diseased petals showing a light brown necrosis were placed in $2 \%$ acidified potato dextrose agar (APDA) with $92 \%$ lactic acid at $0.5 \mathrm{ml}$ per liter and incubated for

TABLE 1. Isolates of Botrytis cinerea and B. prunorum obtained from Japanese plums, nectarine, and peach associated with Botrytis blossom blight in Chile

\begin{tabular}{|c|c|c|c|c|c|}
\hline Season & Isolate & Conidial production $^{\mathrm{z}}$ & Identity & Host & Origin \\
\hline 2012 & Bci-16 & $\mathrm{HCP}$ & B. cinerea & Plum & Pirque \\
\hline 2012 & Bci-35 & $\mathrm{HCP}$ & B. cinerea & Plum & San Francisco \\
\hline 2012 & Bci-32 & $\mathrm{HCP}$ & B. cinerea & Nectarine & San Francisco \\
\hline 2012 & Bpru-8 & $\mathrm{LCP}$ & B. prunorum & Plum & Pirque \\
\hline 2012 & Bpru-21 & $\mathrm{LCP}$ & B. prunorum & Plum & Pirque \\
\hline 2012 & Bpru-49 & $\mathrm{LCP}$ & B. prunorum & Peach & Graneros \\
\hline 2013 & Bci-12 & $\mathrm{HCP}$ & B. cinerea & Nectarine & Rosario \\
\hline 2013 & Bci-14 & $\mathrm{HCP}$ & B. cinerea & Plum & San Francisco \\
\hline 2013 & Bci-15 & $\mathrm{HCP}$ & B. cinerea & Nectarine & San Francisco \\
\hline 2013 & Bci-18 & $\mathrm{HCP}$ & B. cinerea & Nectarine & Pirque \\
\hline 2013 & Bpru-1.2 & $\mathrm{LCP}$ & B. prunorum & Plum & Rosario \\
\hline 2013 & Bpru-1.4 & LCP & B. prunorum & Plum & San Francisco \\
\hline 2013 & Bpru-1.5 & $\mathrm{LCP}$ & B. prunorum & Plum & San Francisco \\
\hline 2013 & Bpru-1.9 & $\mathrm{LCP}$ & B. prunorum & Nectarine & Pirque \\
\hline
\end{tabular}

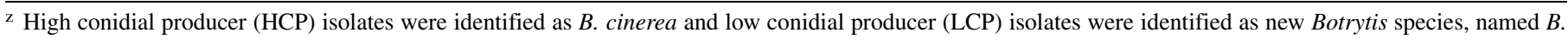
prunorum.

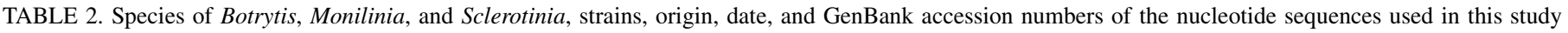

\begin{tabular}{|c|c|c|c|c|c|c|c|c|c|}
\hline \multirow[b]{2}{*}{ Species } & \multirow[b]{2}{*}{ Strains } & \multirow[b]{2}{*}{ Origin } & \multirow[b]{2}{*}{ Date } & \multicolumn{6}{|c|}{ GenBank accession numbers } \\
\hline & & & & ITS & $G 3 P D H$ & HSP60 & $R P B 2$ & $N E P 1$ & $N E P 2$ \\
\hline \multirow[t]{3}{*}{ B. aclada } & MUCL3106 & USA & 1961 & - & AJ704991 & AJ716049 & AJ745663 & - & - \\
\hline & PRI006 & - & - & AJ716295 & AJ704993 & AJ716051 & AJ745665 & - & - \\
\hline & MUCL8145 & Germany & 1965 & - & - & - & - & AM087059 & AM087087 \\
\hline B. byssoidea & MUCL94 & USA & 1923 & - & - & - & - & AM087045 & AM087079 \\
\hline \multirow[t]{3}{*}{ B. calthae } & CBS175.63 & USA & 1961 & AJ716302 & AJ704999 & AJ716060 & AJ745671 & - & - \\
\hline & MUCL1089 & Belgium & 1960 & - & AJ705000 & AJ716061 & AJ745672 & - & - \\
\hline & MUCL2830 & USA & 2005 & - & - & - & - & AM087031 & AM087088 \\
\hline \multirow[t]{3}{*}{ B. caroliniana } & CA3 & USA & 2011 & JF777533 & JF811586 & JF811589 & JF811592 & JF811594 & - \\
\hline & CB15 & USA & 2011 & JF777531 & JF811584 & JF811587 & JF811590 & JF811593 & - \\
\hline & WM4 & USA & 2011 & - & - & - & - & JF811595 & - \\
\hline \multirow[t]{14}{*}{ B. cinerea } & Bci-16 & Pirque, Chile & 2012 & KР091846 & KP120864 & KP136776 & KP120871 & - & - \\
\hline & Bci-32 & San Francisco, Chile & 2012 & KP091847 & KP120865 & KP136777 & KP120872 & - & - \\
\hline & Bci-35 & San Francisco, Chile & 2012 & KP234030 & KP120866 & KP136778 & KP120873 & - & - \\
\hline & Bci-12 & Rosario, Chile & 2013 & KP234031 & KP120867 & KP136779 & KP120874 & - & - \\
\hline & Bci-14 & San Francisco, Chile & 2013 & KP234032 & KP120868 & KP136780 & KP120875 & - & - \\
\hline & Bci-15 & San Francisco, Chile & 2013 & KP234033 & KP120869 & KP136781 & KP120876 & - & - \\
\hline & Bci-18 & Rosario, Chile & 2013 & KP234034 & KP120870 & KP136782 & KP120877 & - & - \\
\hline & B05.10 & Germany & 1994 & - & AJ705002 & AJ716063 & AJ745674 & DQ211824 & DQ211825 \\
\hline & MUCL87y & The Netherlands & 1928 & - & AJ705004 & AJ716065 & AJ745676 & - & - \\
\hline & SAS56 & The Netherlands & 2005 & AJ716294 & AJ705006 & AJ716067 & AJ745677 & - & - \\
\hline & LB338 & The Netherlands & 2005 & - & - & - & - & AM087029 & - \\
\hline & SAS405 & The Netherlands & - & - & - & - & - & AM087028 & - \\
\hline & $\mathrm{BC} 7$ & The Netherlands & - & - & - & - & - & AM087027 & - \\
\hline & $\mathrm{BcB}$ & The Netherlands & 2005 & - & - & - & - & - & AM087090 \\
\hline \multirow[t]{2}{*}{ B. convoluta } & 9801 & The Netherlands & 1998 & AJ716304 & AJ705007 & AJ716068 & AJ745679 & AM087034 & AM087061 \\
\hline & MUCL11595 & USA-The Netherlands & 1968 & - & AJ705008 & AJ716069 & AJ745680 & AM087035 & AM087062 \\
\hline B. croci & MUCL436 & The Netherlands & 2005 & - & - & - & - & AM087047 & AM087065 \\
\hline \multirow[t]{2}{*}{ B. draytonii } & MUCL3865 & The Netherlands & 2005 & - & - & - & - & AM087041 & - \\
\hline & 9701 & The Netherlands & 2005 & - & - & - & - & AM087040 & AM087072 \\
\hline B. deweyae & CBS134649 & Australia & 2013 & - & - & - & - & HG799527 & - \\
\hline \multirow[t]{5}{*}{ B. elliptica } & Be9610 & The Netherlands & 2005 & - & AJ705011 & AJ716072 & AJ745683 & DQ211827 & AM087082 \\
\hline & BE9714 & The Netherlands & 2005 & AJ716300 & AJ705012 & AJ717073 & AJ745684 & AM087049 & AM087089 \\
\hline & BE9401 & The Netherlands & 2005 & - & - & - & - & AM087091 & - \\
\hline & BE0022 & The Netherlands & 2001 & - & - & - & - & AM087050 & AM087081 \\
\hline & Be0004 & The Netherlands & 2005 & - & - & - & - & - & DQ211828 \\
\hline \multirow[t]{4}{*}{ B. fabae } & CBS109.57 & The Netherlands & 1957 & AJ716303 & AJ705013 & AJ716074 & AJ745685 & AM087025 & - \\
\hline & MUCL98 & Spain & 1929 & - & AJ705014 & AJ716075 & AJ745686 & DQ211829 & DQ211831 \\
\hline & MUCL7923 & The Netherlands & 2005 & - & - & - & - & - & DQ211832 \\
\hline & 1104 & Germany & 2012 & - & - & - & - & - & JX266758 \\
\hline \multirow{2}{*}{ B. fabiopsis } & BC-2 & China & 2006 & EU519204 & EU519211 & EU514482 & EU514473 & - & - \\
\hline & BC-13 & China & 2007 & EU563122 & EU563109 & EU563100 & EU563115 & - & - \\
\hline
\end{tabular}

(continued on next page)

y B. cinerea ex-type.

z $B$. mali neotype. 
5 days at $20^{\circ} \mathrm{C}$ in darkness. White to gray colonies were transferred to fresh APDA, and pure cultures were obtained by subcultivating hyphal tips on APDA. Pure cultures were maintained on APDA at $20^{\circ} \mathrm{C}$ for further analysis. The apparently healthy flowers were incubated in humidity chambers $(80 \%$ relative humidity $[\mathrm{RH}])$ for 7 days at $20^{\circ} \mathrm{C}$ before determining the proportion of necrotic flowers. Diseased flowers were incubated in a humid chamber to facilitate sporulation before examining the presence of Botrytis spp. under a stereoscopic microscope, and isolations were performed on APDA.

Cultural characterization and morphological identification. Conidial production was determined initially on APDA. For this purpose, an agar plug ( $5 \mathrm{~mm}$ diameter) was placed individually in the center of 9-cm-diameter Petri dishes containing APDA and were incubated for 7 days at $20^{\circ} \mathrm{C}$ under $12 \mathrm{~h}$ light/dark cycle. Isolates were classified visually as high conidial producers (HCP) and low conidial producers (LCP). To further study conidial production, a subset of seven HCP and seven LCP isolates (Table 1) were arbitrarily selected to quantify conidial production on APDA; King's medium B (KMB), containing per liter $1.5 \mathrm{~g}$ of $\mathrm{K}_{2} \mathrm{KPO}_{4} \cdot 3 \mathrm{H}_{2} \mathrm{O}$, $1.5 \mathrm{~g}$ of $\mathrm{MgSO}_{4} \cdot 7 \mathrm{H}_{2} \mathrm{O}, 10 \mathrm{ml}$ of glycerol, $17 \mathrm{~g}$ of peptone, and $15 \mathrm{~g}$ of agar, as proposed by Li et al. (2012); and pea agar medium (PAM), containing per liter $160 \mathrm{~g}$ of pea (liquefied for $2 \mathrm{~min}$ in 1 liter of distilled water, adjusted to $\mathrm{pH} 6.0$ using $\mathrm{HCl}$ ), $5 \mathrm{~g}$ of sucrose, and $25 \mathrm{~g}$ of agar
(Dahmen et al. 1983). HCP and LCP isolates were plated in quadruplicate in 9-cm-diameter Petri dishes containing the respective agar media and incubated for 7 days at $20^{\circ} \mathrm{C}$ with $12 \mathrm{~h}$ dark and $12 \mathrm{~h}$ light. To determine total conidial production, each plate was flooded with $10 \mathrm{ml}$ of $0.05 \%$ Tween 80 (Sigma Aldrich, MO), and the conidial concentration was estimated with the aid of a hemocytometer under a light microscope.

The morphology and size of the conidia $(n=40)$ and conidiophores $(n=10)$ were studied on PAM incubated for 7 days at $20^{\circ} \mathrm{C}$. Sclerotial production was determined on APDA, KMB, and PAM incubated for 7 days at $20^{\circ} \mathrm{C}$ followed by 30 days at $5^{\circ} \mathrm{C}$ and 30 days at $20^{\circ} \mathrm{C}$. The results were compared with published descriptions of Botrytis species (Mirzaei et al. 2008) (www. mycobank.org).

Molecular characterization. DNA was extracted from the same subset of seven HCP and seven LCP isolates as indicated above (Table 1). The DNA extraction was performed from 7-dayold cultures in potato dextrose broth using the AxyPrep Multisource Genomic DNA Miniprep Kit (Axygen Biosciences, Union City, CA). The internal transcribed spacer (ITS) region, ITS1-5.8SITS2 of the nuclear rDNA was amplified using primers ITS4 and ITS5 (White et al. 1990). The large-subunit (LSU) (26S) ribosomal DNA (rDNA) was amplified with primers NL-1 and NL-4 (Kurtzman and Robnett 1997). The partial DNA sequences of

TABLE 2. (continued from preceding page)

\begin{tabular}{|c|c|c|c|c|c|c|c|c|c|}
\hline \multirow[b]{2}{*}{ Species } & \multirow[b]{2}{*}{ Strains } & \multirow[b]{2}{*}{ Origin } & \multirow[b]{2}{*}{ Date } & \multicolumn{6}{|c|}{ GenBank accession numbers } \\
\hline & & & & ITS & $G 3 P D H$ & HSP60 & $R P B 2$ & $N E P 1$ & $N E P 2$ \\
\hline \multirow[t]{2}{*}{ B. ficariarum } & CBS176.63 & The Netherlands & 2005 & - & - & - & - & AM087056 & AM087085 \\
\hline & MUCL376 & The Netherlands & 2005 & - & - & - & - & AM087055 & - \\
\hline \multirow[t]{2}{*}{ B. galanthina } & MUCL435 & The Netherlands & 1958 & - & AJ705018 & AJ716079 & AJ745689 & - & - \\
\hline & MUCL3204 & The Netherlands & 1963 & - & AJ705017 & AJ716078 & AJ745690 & - & AM087067 \\
\hline \multirow[t]{2}{*}{ B. globosa } & MUCL21514 & The Netherlands & 2005 & - & - & - & - & AM087044 & AM087070 \\
\hline & MUCL444 & The Netherlands & 2005 & - & - & - & - & - & AM087071 \\
\hline \multirow[t]{2}{*}{ B. galanthina } & MUCL435 & The Netherlands & 2005 & - & - & - & - & AM087057 & - \\
\hline & MUCL3204 & The Netherlands & 2005 & - & - & - & - & AM087058 & - \\
\hline B. hyacinthi & 0001 & The Netherlands & 2005 & - & - & - & - & AM087048 & AM087066 \\
\hline B. mali & BPI $412756^{z}$ & USA & 2008 & - & EF367129 & - & - & - & - \\
\hline B. narcissicola & MUCL2120 & The Netherlands & 2005 & - & - & - & - & - & AM087078 \\
\hline \multirow[t]{2}{*}{ B. paeoniae } & 0003 & The Netherlands & 2002 & AJ716298 & AJ705027 & AJ716088 & AJ745699 & AM087032 & AM087064 \\
\hline & MUCL16084 & Belgium & 1970 & - & AJ705028 & AJ716089 & AJ745700 & AM087033 & - \\
\hline \multirow[t]{2}{*}{ B. polyblastis } & CBS287.38 & The Netherlands & 2005 & - & - & - & - & AM087039 & AM087074 \\
\hline & MUCL21492 & The Netherlands & 2005 & - & - & - & - & - & AM087073 \\
\hline \multirow[t]{2}{*}{ B. porri } & MUCL3234 & - & 1926 & AJ716292 & AJ705032 & AJ716093 & AJ745704 & AM087060 & AM087063 \\
\hline & MUCL3349 & Belgium & 1963 & - & AJ705033 & AJ716094 & AJ745705 & - & - \\
\hline \multirow[t]{7}{*}{ B. prunorum } & Bpru-8 & Pirque, Chile & 2012 & KP234035 & KP339979 & KP339993 & KP339986 & KR732657 & KP400595 \\
\hline & Bpru-21 & Pirque, Chile & 2012 & KP234036 & KP339980 & KP339994 & KP339987 & KR732658 & KP400596 \\
\hline & Bpru-49 & Graneros, Chile & 2012 & KP234037 & KP339981 & KP339995 & KP339988 & KR732659 & KP400597 \\
\hline & Bpru-1.2 & Rosario, Chile & 2013 & KP234038 & KP339982 & KP339996 & KP339989 & KR732660 & KR425424 \\
\hline & Bpru-1.4 & San Francisco, Chile & 2013 & KP234039 & KP339983 & KP339997 & KP339990 & KR732661 & KR425425 \\
\hline & Bpru-1.5 & San Francisco, Chile & 2013 & KP234040 & KP339984 & KP339998 & KP339991 & KR732662 & KR425426 \\
\hline & Bpru-1.9 & Pirque, Chile & 2013 & KP234041 & KP339985 & KP339999 & KP339992 & KR732663 & KR425427 \\
\hline \multirow[t]{2}{*}{ B. pseudocinerea } & 10091 & China & 2011 & JN692379 & JN692414 & JN692400 & JN692428 & - & - \\
\hline & N11_S_E06 & Germany & 2012 & - & - & - & - & - & JX266759 \\
\hline B. ranunculi & CBS 178.63 & The Netherlands & 2005 & - & - & - & - & AM087054 & AM087086 \\
\hline \multirow[t]{2}{*}{ B. sinoviticola } & GBC-9 & China & 2009 & JN692378 & JN692408 & JN692394 & JN692422 & - & - \\
\hline & GBC-5 & China & 2010 & JN692386 & JN692413 & JN692399 & JN692427 & - & - \\
\hline \multirow[t]{2}{*}{ B. sinoalli } & OnionBC59 & China & 2007 & FJ169664 & FJ169646 & FJ169658 & FJ169678 & - & - \\
\hline & OnionBC23 & China & 2006 & EU519203 & EU519217 & EU514488 & EU514479 & - & - \\
\hline Botrytis sp. & B83 & Italy & 2012 & KC191680 & KC191677 & KC191678 & KC191679 & KC762944 & KC762945 \\
\hline \multirow[t]{2}{*}{ B. sphaerosperma } & MUCL21481 & The Netherlands & 2005 & - & - & - & - & AM087042 & AM087068 \\
\hline & MUCL21482 & The Netherlands & 2005 & - & - & - & - & AM087043 & AM087069 \\
\hline \multirow[t]{3}{*}{ B. squamosa } & MUCL1107 & USA & 1923 & - & AJ705037 & AJ716098 & AJ745710 & AM087052 & AM087084 \\
\hline & MUCL9112 & The Netherlands & 1966 & - & AJ705038 & AJ716099 & AJ745711 & AM087053 & - \\
\hline & PRI026 & The Netherlands & 2005 & - & - & - & - & AM087051 & AM087083 \\
\hline \multirow[t]{4}{*}{ B. tulipae } & ВТ9001 & The Netherlands & 2000 & - & AJ705040 & AJ716101 & AJ745712 & AM087036 & AM087075 \\
\hline & ВТ9830 & The Netherlands & 2000 & AJ716301 & AJ705041 & AJ716102 & AJ745713 & - & - \\
\hline & Bt005 & The Netherlands & 2005 & - & - & - & - & DQ211822 & DQ211823 \\
\hline & ВТ9901 & The Netherlands & 2005 & - & - & - & - & - & AM087076 \\
\hline M. fructigena & 9201 & The Netherlands & 1992 & - & AJ705043 & AJ716047 & AJ745715 & - & - \\
\hline M. laxa & COY1B5 & France & 1997 & AF150674 & - & - & - & - & - \\
\hline S. sclerotiorum & 484 & The Netherlands & - & - & AJ705044 & AJ716048 & AJ745716 & - & - \\
\hline
\end{tabular}


$G 3 P D H, H S P 60$, and $R P B 2$ genes were amplified with the primer pairs G3PDHfor/G3PDHrev, HSP60for/HSP60rev, and RPB2for/RPB2rev, respectively (Staats et al. 2005).

To further characterize isolates of Botrytis sp. 1, the variation of the nucleotide sequences of the necrosis and ethyleneinducing protein genes (NEP1 and NEP2) was studied, and these sequences were compared with known NEP1 and NEP2 sequences of Botrytis spp. available in GenBank. DNA amplifications were performed with primers NEP1for-NEP1revB and NEP2forE-NEP2revE, as previously described (Staats et al. 2007).

Polymerase chain reactions (PCR) were conducted in a thermal cycler (Axygen Biosciences, Union City, CA). Each PCR sample contained $2.5 \mu \mathrm{l}$ of $10 \times \mathrm{PCR}$ buffer, $1.0 \mu \mathrm{l}$ of $25 \mathrm{mM} \mathrm{MgCl}_{2}, 0.4 \mu \mathrm{l}$ of $10 \mathrm{mM}$ dNTPs, $0.4 \mu \mathrm{l}$ of a $0.5 \mathrm{mM}$ solution of each primer, and $1.2 \mu \mathrm{l}$ of 1 unit of Taq DNA polymerase (Invitrogen, Carlsbad, CA) with $5 \mu \mathrm{l}$ of template DNA in a final volume of $25 \mu \mathrm{l}$. A negative control without template DNA was always included. The thermocycling pattern was the same as that described by Staats et al. (2005), but the annealing temperatures were $55.0^{\circ} \mathrm{C}$ for $G 3 P D H, 54.3^{\circ} \mathrm{C}$ for $H S P 60,49.0^{\circ} \mathrm{C}$ for the $R P B 2$ genes, and $59.0^{\circ} \mathrm{C}$ for the $N E P 1$ and NEP2 genes.

The PCR products were separated on $2 \%$ agarose gel in $1 \times$ Trisacetate-EDTA buffer (TAE), stained with GelRed (Biotium Inc., Hayward, CA), and visualized by UV transillumination at $320 \mathrm{~nm}$. The amplified PCR products were purified and sequenced by Macrogen (Macrogen, Geumcheon-gu, South Korea). The sequences were edited using ProSeq v.2.91 (University of Oxford, UK) and aligned using Clustal X 2.0 (Conway Institute, DU, Ireland). A BLAST search was performed against recognized sequences of Botrytis species in GenBank (www.ncbi.nlm.nih.gov) database (Table 2).

Phylogenetic analysis. The phylogenetic analysis was performed with molecular evolutionary genetics analysis (MEGA 6) software (Tamura et al. 2011), using maximum parsimony, the heuristic search option, and 1,000 random addition sequence replicates. The bootstrap values were evaluated using 1,000 replicates to test the branch strength. The tree length (TL), consistency index $(\mathrm{CI})$, retention index (RI), and rescaled consistency index (RC) were also recorded. This analysis was performed for the sequences of the genes ITS, G3PDH, HSP6O, $R P B 2, N E P 1$, and $N E P 2$. Prior to performing a concatenated analysis of the sequences of the genes G3PDH, HSP6O, and RPB2, the congruence of the evolution between the three genes was studied using the partition homogeneity tests in PAUP v.4.0b10 (Sinauer Associates, Sunderland, MA).

The sequences of the $M$. fructigena strain 9201 and the Sclerotinia sclerotiorum strain 484 were included as outgroups in the phylogenetic analysis of the sequences of the genes $G 3 P D H$, HSP60, and RPB2. M. fructigena strain 9201 was used as an outgroup in the analysis of ITS (Table 2). Terminal regions that did not provide data from every sequence were excluded from the analysis.

Detection of transposable elements. The presence or absence of the transposable elements, Boty and Flipper (Diolez et al. 1995; Levis et al. 1997), was studied in seven HCP and seven LCP isolates (Table 1). The primer pairs used were $\mathrm{LTR}_{98}$ (5- AGCCTGTAGA ATCACCAACG-3), LTR $_{728}$ (5-CGGTATTTCTGGTTGGCA-3), $\mathrm{F}_{300}$ (5-GCACAAAACCTACAGAAGA-3), F1550 (5-ATTCGTT TCTTGGACTGTA-3) for Boty and Flipper, respectively (Muñoz et al. 2002). The PCR reactions were conducted as explained above. The PCR consisted of 30 cycles, denaturation for $3 \mathrm{~min}$ at $95^{\circ} \mathrm{C}$, hybridization for $1 \mathrm{~min}$ at 48 and $60^{\circ} \mathrm{C}$ for Boty and Flipper, respectively, and elongation for $1 \mathrm{~min}$ at $72^{\circ} \mathrm{C}$. Reactions were completed with a final 15 -min elongation step at $72^{\circ} \mathrm{C}$.

PCR products were loaded on a $2 \%$ agarose gel in $1 \times$ Tris-acetateEDTA buffer (TAE), stained with GelRed (Biotium Inc.) and visualized by UV transillumination at $320 \mathrm{~nm}$.
Effect of temperature on mycelial growth. The effect of temperature on the mycelial growth of seven HCP and seven LCP isolates was determined on APDA. Each 90-mm-diameter Petri dish containing APDA was inoculated with a 4-mm diameter mycelial plug of each isolate and plates were incubated at $0,5,10,15,20,25$, 30 , and $35^{\circ} \mathrm{C}\left( \pm 1^{\circ} \mathrm{C}\right)$ in darkness. The colony diameter in each plate was measured daily until the culture reached the edge of the Petri dish. Isolates were incubated in Velp chambers, and the temperatures inside the Petri dishes were checked with a temperature sensor (HOBO PRO, Onset Computer Corp., MA). The growth rate was estimated as the mean growth obtained at 72 and $96 \mathrm{~h}$ of incubation at $25^{\circ} \mathrm{C}$ in darkness for isolates of $B$. cinerea and B. prunorum, respectively. The effect of the Botrytis species and temperature on mycelial growth was analyzed by a two-way (Botrytis species and temperature) analysis of variance using SigmaStat 3.5 (SPSS, Chicago, IL) with four replicates each with one Petri dish.

Pathogenicity tests. Inoculum suspensions were prepared with conidia obtained from 14-day-old cultures on PAM of the respective Botrytis isolates.

Pathogenicity tests were conducted on detached flowers of 'Larry Ann' Japanese plums. Ten detached flowers per isolate were arranged randomly on metal grills, placed in 1-liter polyethylene trays, and sprayed with $100 \mu$ of a $10^{6}$ conidia/ml suspension per flower of each of seven $B$. cinerea and seven Botrytis sp. 1 isolates. Inoculated flowers and the noninoculated controls were incubated for $48 \mathrm{~h}$ at $20^{\circ} \mathrm{C}$ in humid chambers ( $>80 \% \mathrm{RH})$. Each flower was then examined for necrotic petals, and disease severity was expressed as the total number of necrotic petals in the flower. An equal number of flowers treated with sterile distilled water served as controls. Re-isolations from necrotic petals on APDA were attempted. The effect of the Botrytis species and isolates on disease severity was analyzed by a two-way (Botrytis species and isolates) analysis of variance, and means were separated according to Tukey's test $(P<0.05)$ with 10 replicates each consisting of one flower using SigmaStat.

A separate experiment was conducted on flowers of Japanese plums Larry Ann and Flavor Rich to determine the effects of inoculum concentrations on disease severity. Flowers were inoculated with conidial suspensions at $10^{\circ}, 10^{2}, 10^{4}, 10^{6}$, and $10^{8}$ conidia/ml of $B$. cinerea isolate Bci-16 and Botrytis sp. 1 isolate Bpru-1.2, selected among the HCP and LCP Botrytis isolates, respectively. Disease severity was determined as the number of blighted petals per flower after incubation for $48 \mathrm{~h}$ at $20^{\circ} \mathrm{C}$ in humid chambers. The effect of the inoculum concentration on disease severity was analyzed by a two-way (Botrytis species and inoculum concentration) analysis of variance with four replicates each consisting of 10 flowers using SigmaStat. The relationship between $y=$ number of blighted petals and $x=\log$ of inoculum concentration (conidia/ml) was plotted and subjected to regression analysis using SigmaStat.

The ability of seven isolates of $B$. cinerea and seven isolates of Botrytis sp. 1 to decay mature fruits $(n=4)$ was studied on mature (13.5\% mean soluble solids, MSS) Larry Ann Japanese plums using a conidial suspension $\left(10^{6}\right.$ conidia/ml $)$ and mycelial plugs $(4 \mathrm{~mm}$ in diameter) as inoculum. In addition, the ability to decay mature fruits of species other than P. salicina was studied on Granny Smith apples (13.9\% MSS) and on 'Hayward' kiwifruits (10.5\% MSS). The fruits were surface disinfected in $75 \%$ ethanol for $5 \mathrm{~min}$ and wounded with a sterile core borer prior to insertion of a mycelial plug $(4 \mathrm{~mm}$ in diameter) underneath the epidermis. Fruits were incubated for 2 to 4 days at $20^{\circ} \mathrm{C}$ in humid chambers before the diameters of the necrotic lesions were determined. An equal number of noninoculated but injured fruits were left as controls. The effect of the Botrytis species and isolates on the necrotic lesions was analyzed by a two-way (Botrytis species and isolates) analysis of variance, and means were separated according to Tukey's test $(P<$ 
0.05) with four replicates each consisting of one fruit using SigmaStat.

\section{RESULTS}

Species and distribution of Botrytis. In total, 1,026 isolates of Botrytis spp. were obtained from diseased and apparently healthy Japanese flowers between the 2012 and 2014 growing seasons, with $33.9 \%$ of the isolates from diseased blossoms and $66.1 \%$ from apparently healthy flowers. In addition, one and five isolates were identified on peach and nectarine flowers, respectively. Symptoms started as small light brown mottles on the petals. Lesions expanded rapidly and eventually affected the entire petals. The stamens and pistil eventually also turned brown. AV-shaped necrotic lesion often appeared on petals in the early stage of symptom development. Blighted flowers fell from the trees. Under humid conditions, a gray sporulation appeared on diseased organs. No symptoms were observed on twigs and spurs (Fig. 1).

On the basis of morpho-cultural characteristics and molecular analysis of the DNA, of the 1,026 isolates tested, $90.4 \%$ of the isolates were HCP isolates and identified as B. cinerea, and $9.6 \%$ of the isolates were LCP isolates (Botrytis sp.1). Botrytis sp. 1 and $B$. cinerea were isolated from diseased blossom and apparently healthy flowers and they were present in all six sampling locations. Botrytis sp. 1 was identified as B. prunorum sp. nov. in this study.

B. prunorum E. E. Ferrada \& B. A. Latorre sp. nov. (Figs. 2 and 3) MycoBank MB814437.

B. prunorum is described here as a new species of Botrytis that was commonly isolated along with $B$. cinerea from apparently healthy and blossom blight-affected Japanese plums.

B. prunorum grew $23.2 \pm 1.2 \mathrm{~mm}$ per day at $25^{\circ} \mathrm{C}$, producing white to yellowish colonies, with floccose and tufted aerial mycelia, with scarce sporulation, with a conidial production ranging from 0 to 9.9 conidia/ $\mathrm{cm}^{2}$ on APDA (Fig. 2). Colonies of B. cinerea sensu stricto were white to gray, with less fluffy aerial mycelia and grew at

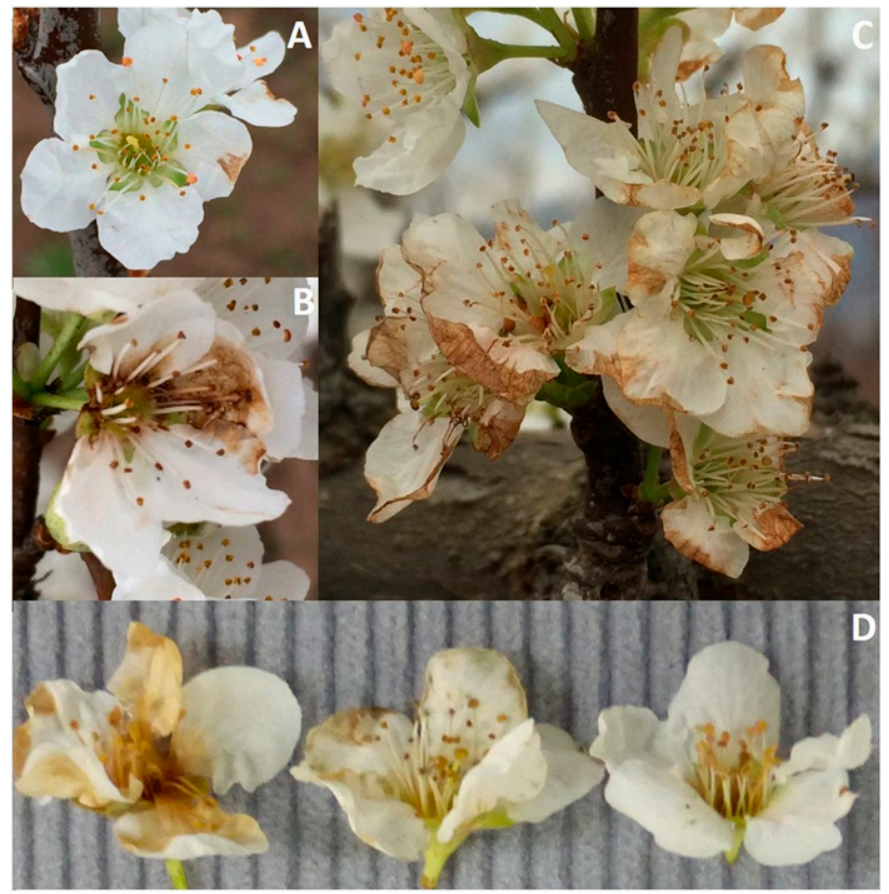

Fig. 1. Symptoms of Botrytis blossom blight in flowers of Japanese plum 'Larry Ann'. A, V-shaped necrotic lesion starting at the edge of the petal. B, Petal, stamen, and pistil necrosis. C, Blighted blossom. D, Symptoms on flowers artificially inoculated with conidial suspension of the pathogens; from left to right, $B$. cinerea, $B$. prunorum, and sterile distilled water control.

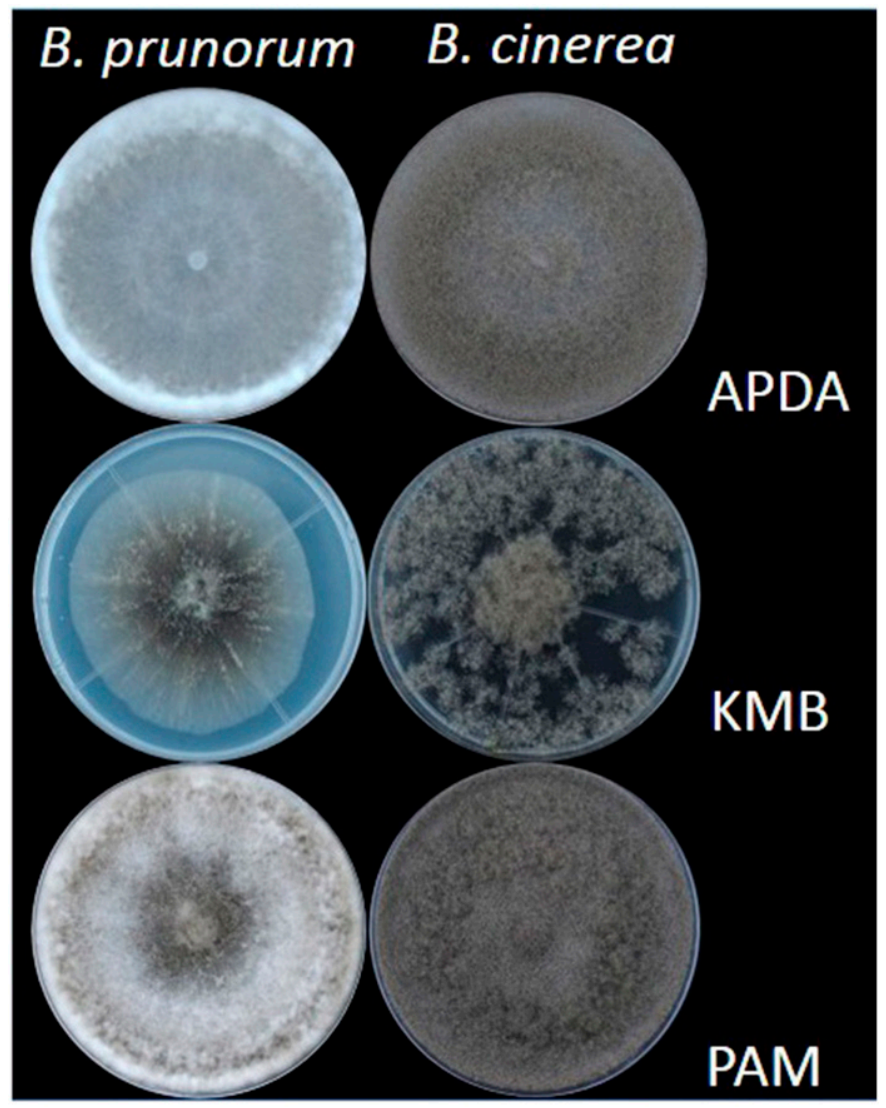

Fig. 2. Colony morphology of isolates of Botrytis prunorum and B. cinerea on acidified potato dextrose agar (APDA), King's medium B (KMB), and pea agar medium (PAM) incubated for 7 days at $20^{\circ} \mathrm{C}$ with a $12 \mathrm{~h}$ light $/ 12 \mathrm{~h}$ dark cycle.

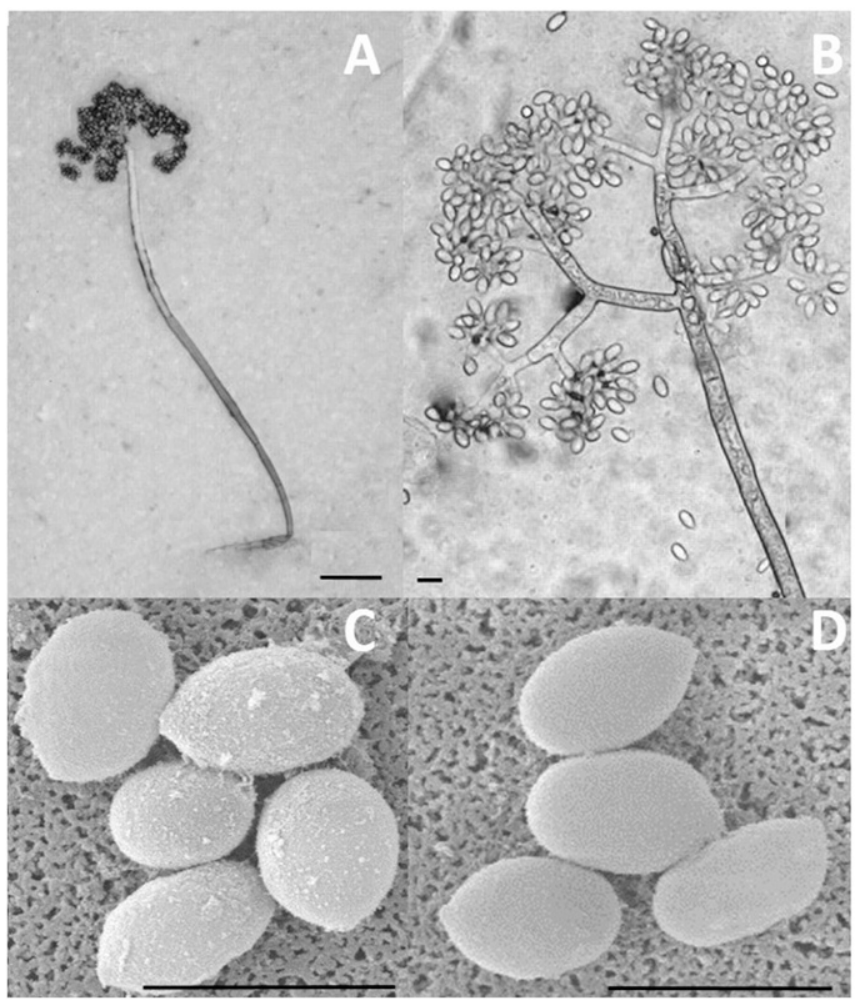

Fig. 3. Morphology of conidiophores and conidia of Botrytis prunorum. A, Long septate conidiophore, dark and constricted at the base and hyaline and branched at the apex. B, Branched conidiophore with oval to ellipsoidal hyaline to slightly colored conidia. Conidial morphology under scanning electron microscopy of $\mathbf{C}$, B. prunorum and D, B. cinerea. Bar $=100 \mu \mathrm{m}(\mathbf{A})$ and $10 \mu \mathrm{m}(\mathbf{B}, \mathbf{C}$, and D). 
a rate of $27.4 \pm 1.1 \mathrm{~mm}$ per day on APDA. Conidial production of $B$. cinerea was significantly $(P<0.001)$ higher than that of $B$. prunorum, ranging from 31.8 to 487.2 conidia $/ \mathrm{cm}^{2}$ (Fig. 2). Colonies of $B$. prunorum were flat white-creamy to brown in the center on KMB and white floccose with a gray to brown center on PAM, while colonies of $B$. cinerea were gray floccose with uneven growth on KMB and gray, fluffy, and floccose on PAM (Fig. 2).

The composition of the culture media significantly $(P<0.001)$ affected the quantity of conidia produced by both Botrytis species, with the highest conidial production on PAM and the lowest on $\mathrm{KMB}$. The interaction between the Botrytis species and the culture media was significant $(P=0.001)$.

B. prunorum produced sclerotia at $5^{\circ} \mathrm{C}$, but not at $20^{\circ} \mathrm{C}$, on APDA and $\mathrm{KMB}$ after 30 days, and one of the seven isolates produced few sclerotia on PAM at $20^{\circ} \mathrm{C}$. B. cinerea produced sclerotia on APDA and PAM at 5 and $20^{\circ} \mathrm{C}$. Differences in sclerotial production at $5^{\circ} \mathrm{C}$ on APDA and PAM were significant (Table 3). The sclerotia of B. prunorum and B. cinerea were black, ovoid to elongate, and randomly distributed on Petri plates containing either APDA or PAM with a mean length of $2.92 \pm 1.07$ and mean width of $3.11 \pm 1.33 \mathrm{~mm}$ for $B$. prunorum and mean length of $5.39 \pm 1.49$ and mean width of $4.35 \pm 1.09 \mathrm{~mm}$ for B. cinerea (Table 3 ).

The conidiophores of $B$. prunorum isolates were erect, thickwalled, smooth, septate, subhyaline at the base and the apex and brown in the middle, slightly constricted at the base, gradually tapering toward the apex, irregularly branched toward the apex (Fig. $3 \mathrm{~A}$ and $\mathrm{B}$ ), and 508.7 to $1,004.8 \mu \mathrm{m}$ in length and 10.4 to $14.6 \mu \mathrm{m}$ in width. The conidia were mostly ovoid, hyaline to slightly colored, smooth, with a slightly protuberant hilum (Fig. 3C) similar to conidia of B. cinerea (Fig. 3D). The conidia of B. prunorum were 5.9 to $20.8 \mu \mathrm{m}$ in length and 4.8 to $12.9 \mu \mathrm{m}$ in width. The length/width ratio was $1.6 \pm 0.3$ for $B$. prunorum and $1.3 \pm 0.03$ for $B$. cinerea isolates (Table 3 ). Chlamydospores and microconidia were not found, and teleomorphs were not present.

Etymology: "prunorum" refers to the genus of the host from which the fungus was isolated.
Specimen examined: Chile, San Francisco de Mostazal $\left(33^{\circ} 59^{\prime} 53^{\prime \prime} \mathrm{S}, 70^{\circ} 41^{\prime} 38^{\prime \prime} \mathrm{W}\right)$, a dried culture of the isolate Bpru-21 isolated from Prunus salicina (Japanese plum) flowers, September 2012, collectors E.E. Ferrada and B.A. Latorre (Holotype BPI893191 [U.S. National Fungus Collection accession number]); CBS140338 initiated from the holotype has been deposited as an authentic ex-type culture. Pirque, Chile $\left(33^{\circ} 40^{\prime} 10^{\prime \prime} \mathrm{S}\right.$, $70^{\circ} 35^{\prime} 09^{\prime \prime} \mathrm{W}$ ), a dried culture of the isolate Bpru-1.9 isolated from Prunus persica var. nectarina (nectarine) flowers, September 2013, collectors E.E. Ferrada and B.A. Latorre (Paratype BPI893192); CBS140337 has been deposited as a living culture of the isolate Bpru-1.9.

Molecular characterization. The ITS1-5.8S-ITS2 regions for all $B$. prunorum isolates and $B$. cinerea isolates were successfully amplified, obtaining 492-bp fragments. In Blast searches of the GenBank database, these fragments, obtained with primers ITS4 and ITS5, were $100 \%$ identical to the published sequences of B. cinerea isolates deposited in GenBank (Table 2). Similarly, the LSU amplification yielded fragments of 478 bp (Accession numbers KT023582-88 and KT023589-95), which were 99\% identical to the published LSU sequences of B. cinerea B05.10 deposited in GenBank (Accession number CP009808).

Regions of the G3PDH, HSP60, and RPB2 genes for all seven $B$. prunorum isolates and seven $B$. cinerea isolates were amplified, and 886, 976, and 1,093-bp DNA fragments were obtained, respectively. The G3PDH DNA sequences obtained for the isolates of $B$. prunorum had $99 \%$ identity with that of a reference sequence of $B$. cinerea (strains SAS56 and MUCL87), 98 to $99 \%$ identity with that of B. mali (strain BPI 412756), and 98 to $99 \%$ identity with that of $B$. paeoniae (strain 0003). The same B. prunorum isolates were $97 \%$ identical to $H S P 60$ sequences and 97 to $98 \%$ identical to RPB2 sequences of $B$. paeoniae.

All isolates of $B$. prunorum and $B$. cinerea were consistently detected by primers NEP1for-NEP1revB and NEP2 for-NEP2revE. Amplicons of 687 and 743 bp were obtained for NEP1 and NEP2 genes for B. prunorum, which showed 87 and $88 \%$ identity with $B$. cinerea strain B05.10, respectively. The BLAST analysis of NEP

TABLE 3. Morphological characteristics of Botrytis prunorum and to B. cinerea isolates from Japanese plums

\begin{tabular}{|c|c|c|c|}
\hline Criteria $^{y}$ & B. cinerea & B. prunorum & $P$ value \\
\hline Growth rate on APDA at $25^{\circ} \mathrm{C}, \mathrm{mm} /$ day & $27.4 \pm 1.1^{\mathrm{z}}$ & $20.3 \pm 0.8$ & $<0.001$ \\
\hline \multicolumn{4}{|l|}{ Conidia production at $20^{\circ} \mathrm{C}$ on: } \\
\hline APDA, conidia/ $\mathrm{cm}^{2}$ & $206.0 \pm 174.2$ & $2.1 \pm 3.8$ & 0.007 \\
\hline $\mathrm{PAM}$, conidia $/ \mathrm{cm}^{2}$ & $767.1 \pm 247.7$ & $9.9 \pm 10.8$ & $<0.001$ \\
\hline \multicolumn{4}{|l|}{ Conidia length $(\mathrm{L})$ : } \\
\hline Mean, $\mu \mathrm{m}$ & $9.6 \pm 1.1$ & $11.1 \pm 1.6$ & \multirow[t]{2}{*}{$<0.001$} \\
\hline Range, $\mu \mathrm{m}$ & $7.4-12.8$ & $5.9-20.8$ & \\
\hline Range, $\mu \mathrm{m}$ & $5.2-10.0$ & $4.8-12.9$ & 0.966 \\
\hline $\mathrm{L}: \mathrm{W}$ ratio & $1.3 \pm 0.03$ & $1.6 \pm 0.3$ & 0.054 \\
\hline \multicolumn{4}{|l|}{ Conidiophore length: } \\
\hline Mean, $\mu \mathrm{m}$ & $1,172.2 \pm 331.9$ & $711.7 \pm 104.7$ & \multirow[t]{2}{*}{$<0.001$} \\
\hline Range, $\mu \mathrm{m}$ & $464.0-2,555.1$ & $315.0-1,380.2$ & \\
\hline \multicolumn{4}{|l|}{ Conidiophore width: } \\
\hline Mean, $\mu \mathrm{m}$ & $12.8 \pm 2.0$ & $11.8 \pm 2.0$ & 0.231 \\
\hline \multicolumn{4}{|l|}{ Sclerotia production at $5^{\circ} \mathrm{C}$ on: } \\
\hline $\mathrm{KMB}, \mathrm{no} . / \mathrm{cm}^{2}$ & $0.00 \pm 0.00$ & $0.00 \pm 0.00$ & 0.268 \\
\hline PAM, no. $/ \mathrm{cm}^{2}$ & $0.25 \pm 0.19$ & $0.56 \pm 0.66$ & 0.253 \\
\hline \multicolumn{4}{|l|}{ Sclerotia production at $20^{\circ} \mathrm{C}$ on: } \\
\hline APDA, no. $/ \mathrm{cm}^{2}$ & $0.60 \pm 0.49$ & $0.00 \pm 0.00$ & \multirow[t]{2}{*}{0.008} \\
\hline $\mathrm{KMB}, \mathrm{no} . / \mathrm{cm}^{2}$ & $0.00 \pm 0.00$ & $0.00 \pm 0.00$ & \\
\hline $\mathrm{PAM}$, no. $/ \mathrm{cm}^{2}$ & $1.23 \pm 0.58$ & $0.02 \pm 0.06$ & $<0.001$ \\
\hline
\end{tabular}

y $\mathrm{APDA}=$ acidified potato dextrose agar, $\mathrm{KMB}=$ King's medium $\mathrm{B}$, and PAM = pea agar medium.

${ }^{\mathrm{z}}$ Mean values of seven isolates for each species followed by standard deviation. 
sequences of $B$. prunorum indicated $91 \%$ identity with $B$. porri in $N E P 1$ (strain MUCL3234) and 93\% identity with B. squamosa in $N E P 2$ (strain PRI026). The sequences of the ITS, G3PDH, HSP6O, and $R P B 2$ from $B$. prunorum and B. cinerea isolates obtained from Japanese plums, peaches, and nectarines were deposited in GenBank and sequences of NEP1 and NEP2 from B. prunorum also were deposited in GenBank (Table 2).

Phylogenetic analysis. The phylogenetic analysis, using sequences of the ITS gene, grouped $B$. cinerea and B. prunorum isolates in two different clusters and various subclusters along with other Botrytis species (data not shown).

The phylogenetic analysis, performed separately based on the sequences obtained from the G3PDH, HSP60, and RPB2 genes, showed that all $B$. prunorum isolates were grouped together in the same cluster distantly from the cluster where $B$. cinerea isolates were grouped. Other Botrytis species such as B. mali and B. paeoniae were grouped separately.

The partition-homogeneity test performed with the sequences of $G 3 P D H, H S P 60$, and $R P B 2$ was nonsignificant $(P=0.81)$.
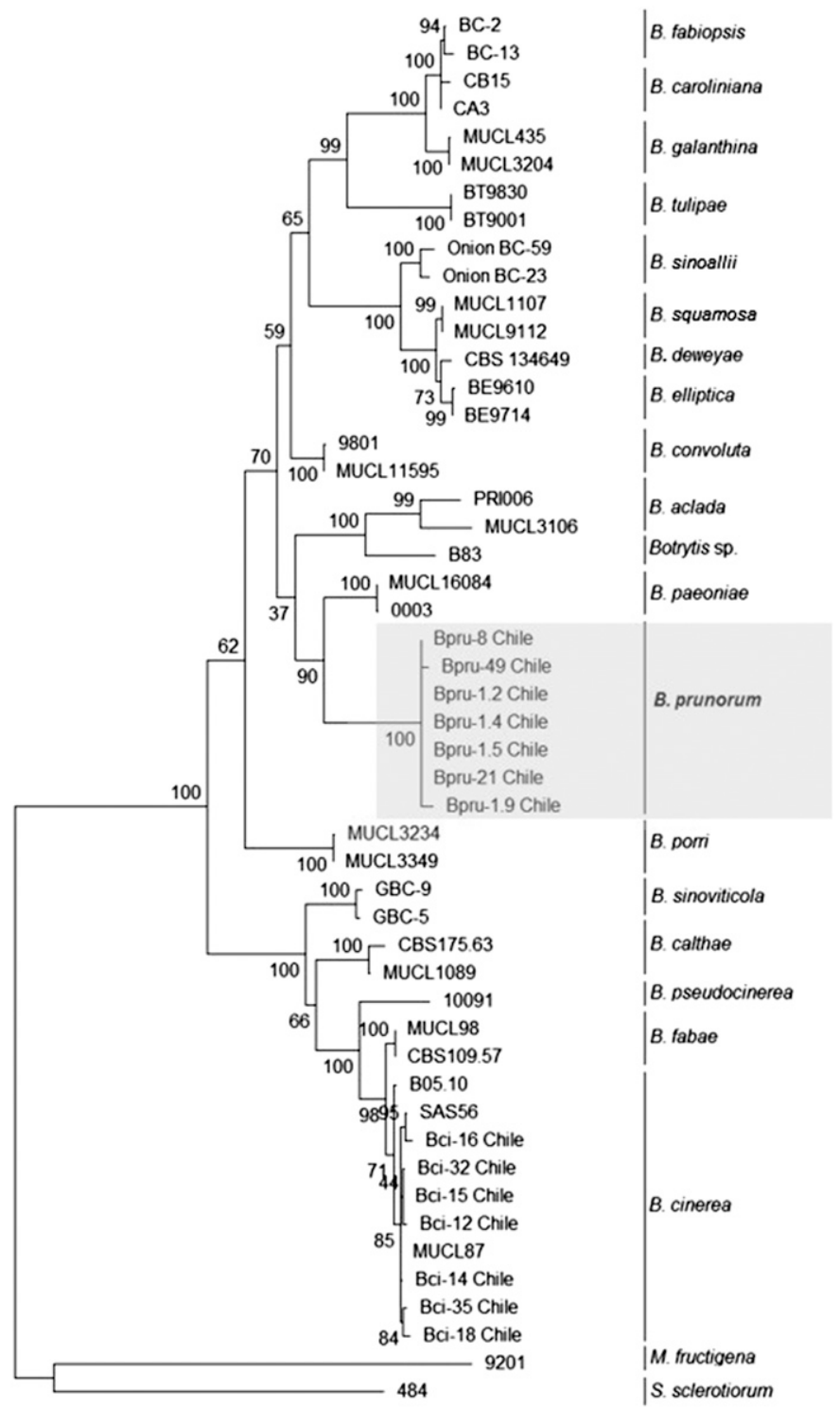

\section{0}

Fig. 4. Phylogenetic analysis of 50 taxa of Botrytis spp. in a maximum parsimony tree inferred from the data set based on concatenated DNA sequences of $G 3 P D H, H S P 60$, and RPB2 using MEGA 6.0.
Therefore, a maximum parsimony analysis of concatenate $G 3 P D H$, $H S P 60$, and RPB2 sequences was performed, yielding a single most parsimonious tree (Fig. 4). Based on maximum parsimony analysis, the six most parsimonious trees yielded tree length $(\mathrm{TL})=1038$, consistency index $(\mathrm{CI})=0.717$, retention index $(\mathrm{RI})=0.895$, and recalled consistency index $(\mathrm{RC})=0.642$. All isolates of $B$. prunorum were grouped together in a separate clade with $100 \%$ bootstrap value distantly related to $B$. cinerea (Fig. 4).

On the basis of the phylogenetic analysis of NEPI sequences, B. prunorum isolates were grouped in the same clade with $100 \%$ bootstrap value, very distantly from $B$. cinerea (Fig. 5). Similarly, sequence analysis of the $N E P 2$ gene of all $B$. prunorum isolates were grouped in the same clade with $99 \%$ bootstrap value, distinct from the $B$. cinerea clade (data not shown). The phylogenetic analysis revealed that sequences of $B$. porri and $B$. squamosa, which

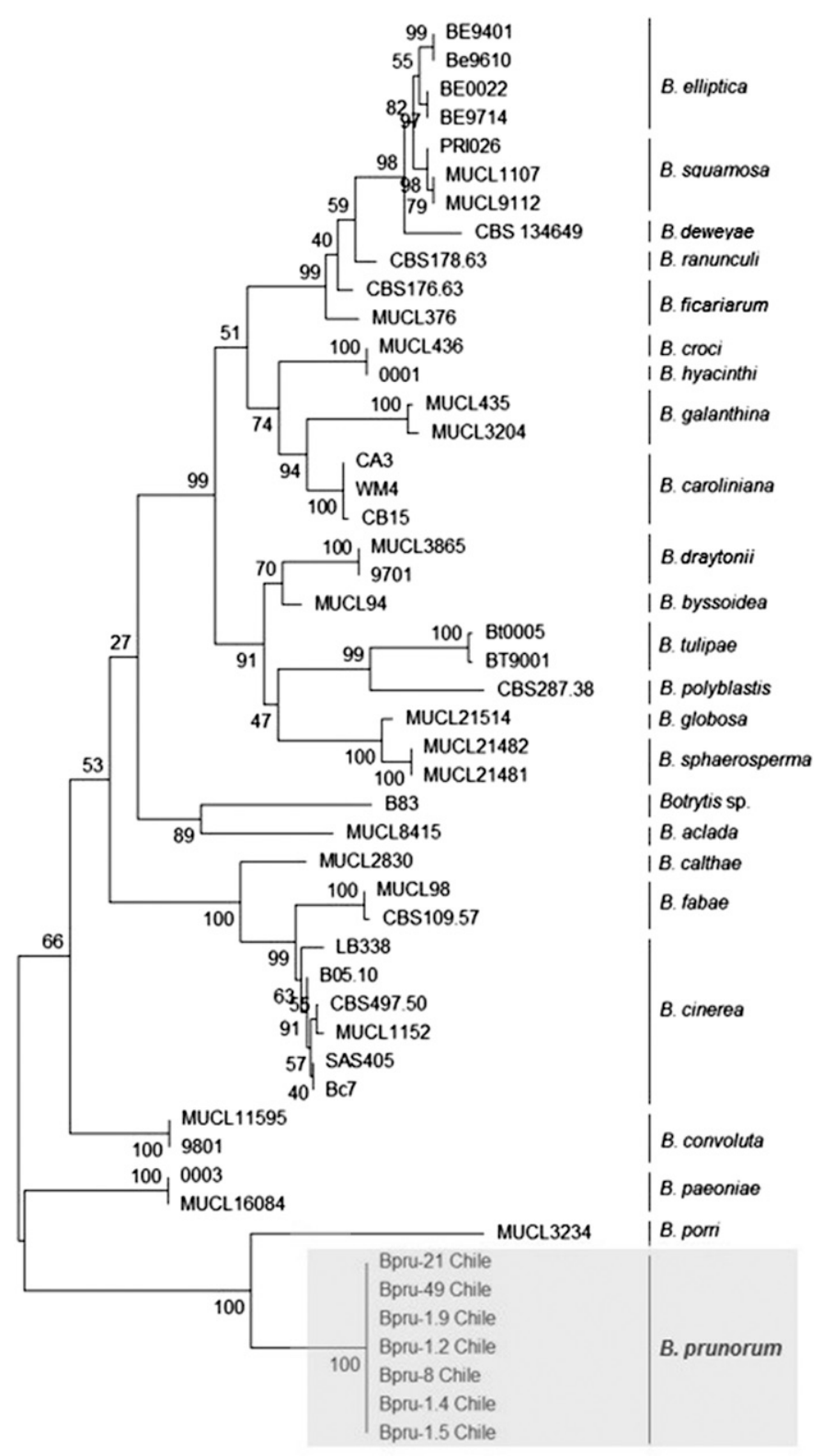

10

Fig. 5. Phylogenetic analysis of 50 taxa of Botrytis spp. in a maximum parsimony tree inferred from the DNA sequence encoding necrosis and ethyleneinducing protein 1 (NEP1) among B. prunorum isolates and other Botrytis species. 
were the closest Botrytis sequences to B. prunorum based on NEP2 BLAST analysis, were grouped distantly from $B$. prunorum.

Detection of transposable elements. The analysis of the presence/absence of the transposable elements Boty and Flipper (Diolez et al. 1995; Levis et al. 1997) in B. cinerea and B. prunorum from Japanese plums revealed a 648-bp amplicon, as expected for Boty, in two (isolates Bci-14 and Bci-18) of the seven B. cinerea isolates and in six (Bpru-8, Bpru-49, Bpru-1.2, Bpru-1.4, Bpru-1.5, and Bpru-1.9) of the seven B. prunorum isolates. Evidence for the presence of the transposable element Flipper was not obtained.

Effect of temperature on mycelial growth. Mycelial growth was significantly $(P<0.001)$ affected by the Botrytis species and temperature. The interaction between Botrytis species and temperature was significant $(P<0.001)$. All isolates of $B$. prunorum and $B$. cinerea grew at temperatures between 5 and $30^{\circ} \mathrm{C}$, but no growth was observed after $96 \mathrm{~h}$ at $35^{\circ} \mathrm{C}$. One isolate of $B$. cinerea and five isolates of $B$. prunorum exhibited slight mycelial growth after $96 \mathrm{~h}$ at $0^{\circ} \mathrm{C}$. The optimum temperature for mycelial growth was estimated to be $25^{\circ} \mathrm{C}$ for both $B$. cinerea and B. prunorum.

Pathogenicity test. When conidial suspension was used as inoculum, all isolates of $B$. prunorum and $B$. cinerea were pathogenic on flowers of Japanese plums Larry Ann (Table 4). Inoculated flowers developed a similar light brown necrosis of the petals that often started as light brown mottles or V-shaped necrosis at the margins of the petals, and necrosis was also observed in the stamens and pistils (Fig. 1D). Isolates of B. cinerea caused significantly $(P<0.001)$ higher numbers of blighted petals on flowers than $B$. prunorum, except the isolate Bpru-1.2, indicating that $B$. prunorum was less virulent than $B$. cinerea (Table 4 ). $B$. prunorum and $B$. cinerea were re-isolated from artificially inoculated flowers. No symptoms were observed on noninoculated flowers.

On flowers of Japanese plums Larry Ann and Flavor Rich, a second order polynomial model best explained the relation between the $\log$ inoculum concentration of $B$. cinerea and disease severity (the number of blighted petals per flower) with $y=4.72 x^{2}-15.88 x+$ $28.41\left(R^{2}=0.99, P=0.007\right)$ and $y=4.15 x^{2}-8.30 x+11.64\left(R^{2}=\right.$ $0.94, P=0.057)$ for Larry Ann and Flavor Rich, respectively
(Fig. 6). For B. prunorum, the relationship between the inoculum concentration and the number of blighted petals was best explained by a linear relationship with $y=5.96 x+5.34\left(R^{2}=0.79, P=0.044\right)$ and $y=3.23 x+2.42\left(R^{2}=0.98, P=0.001\right)$ for Larry Ann and Flavor Rich, respectively (Fig. 6).

All isolates of $B$. cinerea and $B$. prunorum caused dark brown soft decay lesions on mature fruits of Larry Ann plums inoculated with conidia or mycelial plugs. Decay lesion sizes on the fruit inoculated with $B$. prunorum were significantly $(P<0.001)$ smaller than those inoculated with $B$. cinerea, regardless of inoculum type (Table 4). However, when mycelial plugs were used as inoculum, decay lesion sizes did not differ significantly among the isolates of $B$. cinere $a$ and B. prunorum (Table 4).

All tested isolates of $B$. cinerea and $B$. prunorum caused dark brown decay lesions on apples and kiwifruits, and decay lesion sizes on the fruit inoculated with $B$. prunorum were significantly $(P<$ $0.001)$ smaller than those inoculated with $B$. cinerea (Table 4$)$. The pathogens were re-isolated from artificial inoculated fruit.

\section{DISCUSSION}

In this study, species of Botrytis were consistently isolated from blossom blight of Japanese plums in Central Chile, and we confirmed the earlier report of association of $B$. cinerea with this disease (Ferrada et al. 2015) and identified B. prunorum sp. nov. as a new Botrytis species. Previously, blossom blight caused by B. cinerea was reported on plums in California (Ogawa and English 1960) and South Africa (Fourie and Holz 1994).

Blossom blight reduces fruit set, and symptoms resemble those caused by M. fructicola and M. laxa, which are considered the most important pathogens responsible for this disease on plums and other stone fruit trees around the world (Ogawa et al. 1995). Unlike Monilinia infection, Botrytis spp. are always restricted to blossoms and never continue to the partially lignified spurs and twigs. The occurrence of this disease varies from year to year.

Disease incidence was estimated to range from 4 to $53 \%$ in 2013 and 2014. This variation in prevalence could be explained by differences in the microclimatic conditions (free moisture and temperature) in orchards during bloom stage, as reported previously

TABLE 4. Pathogenicity of isolates of Botrytis cinerea and B. prunorum on flowers of Japanese plum Larry Ann and mature fruit of Japanese plum, Granny Smith apple, and Hayward kiwifruit

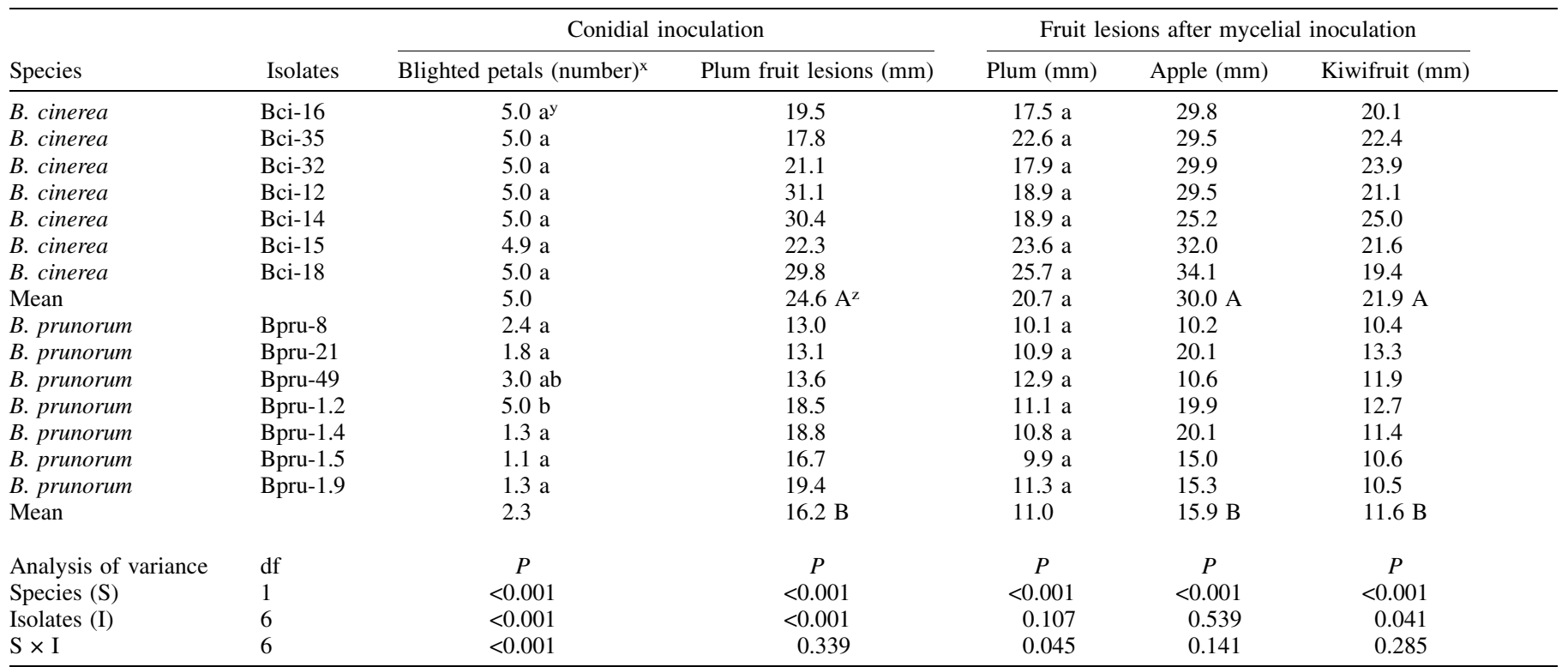

${ }^{\mathrm{x}}$ Petals $(n=50)$ were inoculated with $100 \mu \mathrm{l}$ per flower of a conidial suspension of $10^{6}$ conidia/ml incubated in humid chambers at $20^{\circ} \mathrm{C}$ for $48 \mathrm{~h}$. Fruits $(n=4)$ were inoculated with a 4-mm-mycelial plug obtained from 7-day-old cultures on acidified potato dextrose agar.

y Values followed by the same lowercase letter in the same column with the same species did not differ significantly according to Tukey's test $(P<0.05)$.

${ }^{\mathrm{z}}$ Means followed by the same uppercase letter in each column did not differ significantly according to Tukey's test $(P<0.05)$. 
for B. cinerea infection of other hosts (Elmer and Michailides 2004; Latorre et al. 2015). However, the relationship between Botrytis blossom blight in Japanese plums and weather factors remains to be studied.

Isolates of $B$. cinerea and B. prunorum were pathogenic, inducing flower blight and fruit rot on Japanese plums inoculated with conidia or mycelium of the fungi. These pathogens were re-isolated only from inoculated and diseased tissues. Thus, Koch's postulates were fulfilled with $B$. cinerea and B. prunorum, confirming its role in the blossom blight of Japanese plums. Further studies are still needed to determine the presence and the role of B. prunorum in fruit infection. Given that ascospores of $B$. prunorum were not found, it is most likely that infections may be initiated from airdispersed conidia in nature that are produced in multiple and very diverse sources of primary inoculum, as described for $B$. cinerea on other hosts (Holz et al. 2004; Williamson et al. 2007). The ability of conidia of $B$. cinerea to germinate and form appressoria on plum flowers has been studied previously (Fourie and Holz 1994). However, the sources of inoculum of $B$. prunorum remain to be determined.

Both $B$. cinerea and B. prunorum were isolated consistently from blighted blossoms and apparently healthy flowers. However, $B$. cinerea was always the predominant species that was identified in 91.7 and $89.8 \%$ of the isolates obtained from blighted flowers and apparently healthy flowers, respectively. Our results suggest that $B$. prunorum was less fit than $B$. cinerea because of the low proportion of $B$. prunorum isolates. This finding can, at least in part, be explained by the relatively low conidia production, which is the principal inoculum and dispersal structure for B. cinerea (Holz et al. 2004), the relatively slow growth rate that reduces the aggressiveness of this pathogen, and the low sclerotial production, which likely play an important role in survival (Coley-Smith 1980).

$B$. cinerea is a polyphagous and necrotrophic fungus with a wide host range, including over 200 hosts primarily among dicotyledonous plants (van Kan et al. 2014; Williamson et al. 2007). Recently, the capability of $B$. cinerea to internally colonize plants, possibly as an endophyte, has been discussed (Delaye et al. 2013; van Kan et al. 2014). Whether this endophytic life style is also present in $B$. prunorum remains to be determined. Interestingly, $B$. cinerea and $B$. prunorum were found as epiphytes in this study, suggesting that both Botrytis species can have a facultative pathogenic behavior. The host range of $B$. prunorum remains to be studied. However, B. prunorum was found on blighted flowers of nectarine and peach, and isolates of this species were pathogenic on apple and kiwifruit, suggesting that $B$. prunorum is a nonspecific Botrytis species. In addition, $B$. prunorum and $B$. cinerea were consistently isolated from apparently healthy flowers.

The pathogenicity of $B$. cinerea and $B$. prunorum was demonstrated on artificially inoculated Japanese plum flowers and on the fruits of plum, apple, and kiwifruits. However, $B$. prunorum was less virulent than $B$. cinerea. Furthermore, regardless of the Botrytis species, the number of blighted petals increased with increasing inoculum concentration, but steeper increases in the number of blighted petals were obtained with $B$. cinerea than B. prunorum, and at any given inoculum concentration, the amount of blighted petals was always significantly $(P<0.05)$ higher with $B$. cinerea than $B$. prunorum. These results reinforce the difference in virulence observed between these two species of Botrytis.

The occurrence of mycovirus in B. cinerea has been studied previously (Castro et al. 2003; Pearson and Bailey 2013), and it has been demonstrated that the presence of mycoviruses and/or the expression of mycoviral genomes conferred the hypovirulence phenotypes to the host fungus (Nuss 2005; Potgieter et al. 2013). Our preliminary research indicated the evidence for the presence of mycovirus in isolates of $B$. prunorum, but additional research is underway to obtain conclusive and definitive results. Therefore, it is likely that the presence of mycoviruses may explain the lower virulence exhibited by $B$. prunorum isolates. Nevertheless, differences in virulence between $B$. cinerea and $B$. prunorum could also be attributed to differences in the genetic expression of virulence factors.

Isolates of $B$. prunorum were morphologically and phylogenetically distinct from isolates of $B$. cinerea. Our results indicated that isolates of $B$. prunorum can be distinguished from $B$. cinerea by their colony morphology, conidia length, conidiophore length, sclerotia production on PAM at $20^{\circ} \mathrm{C}$, and the amount of sporulation on APDA, KMB, and PAM. On average, isolates of $B$. prunorum produced $99 \%$ fewer conidia on APDA than isolates of $B$. cinerea.

As previously reported for other Botrytis species, the analysis of ITS regions 1 and 2 was not very informative for differentiating B. prunorum from B. cinerea (Li et al. 2012; Staats et al. 2005; Zhang et al. 2010a,b), nor analysis of the LSU of the rDNA performed according to Kurtzman and Robnett (1997). Therefore, the information obtained with ITS sequences and LSU sequences was insufficient to establish the taxonomic status of Botrytis isolates in this study. However, the phylogenetic analyses of the sequences of the nuclear genes $G 3 P D H, H S P 60$, and $R P B 2$, previously used for the revision of Botrytis species (Staats et al. 2005), clearly separated B. prunorum from B. cinerea. Similarly, the amplification and sequence analysis of NEP1 and NEP2 genes (Staats et al. 2007)

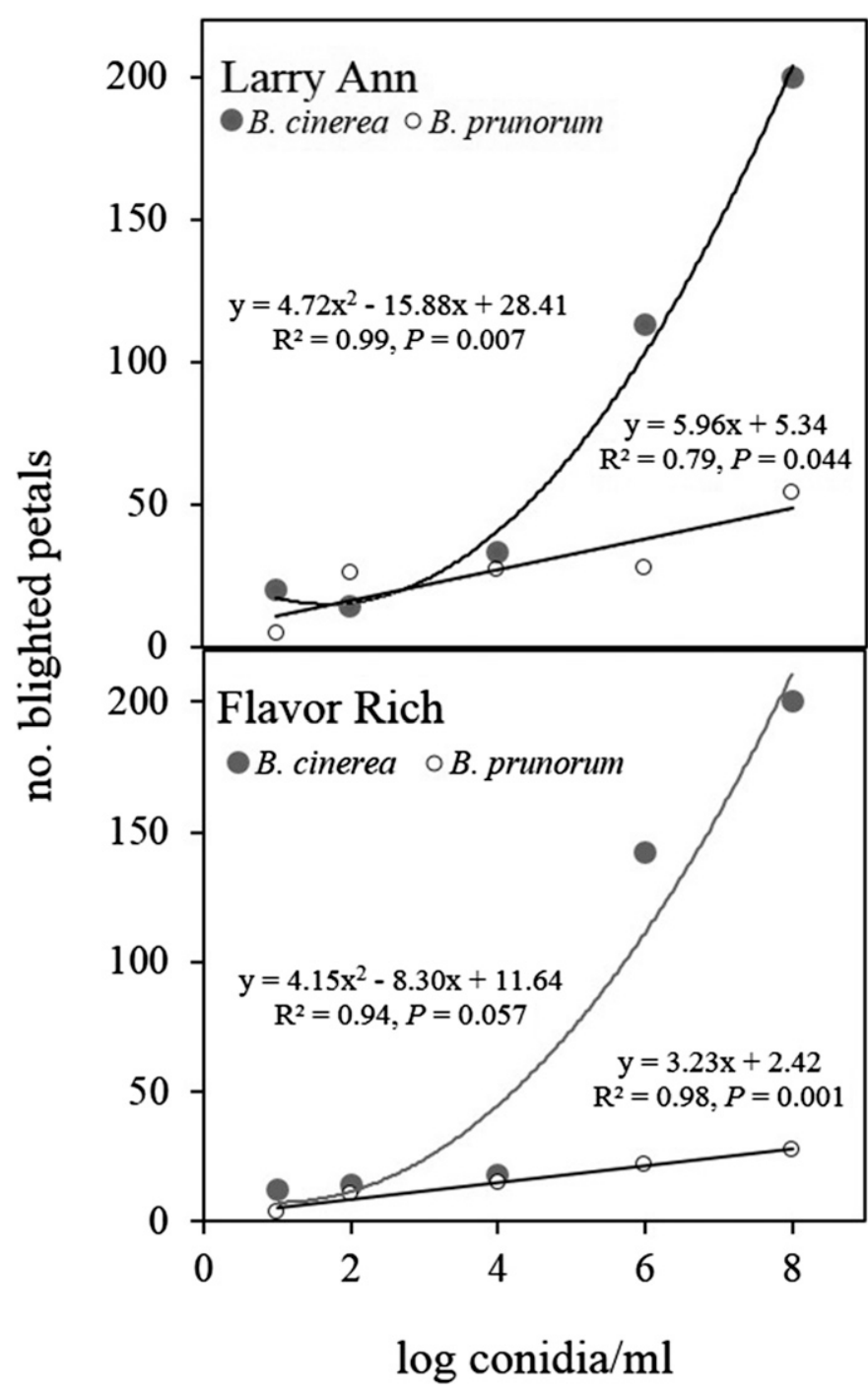

Fig. 6. Effect of inoculum concentration of Botrytis cinerea and B. prunorum on disease severity obtained on flowers of Japanese plum 'Larry Ann' and 'Flavor Rich'. The relationship between $y=$ number of blighted petals and $x=$ $\log$ of inoculum concentration (conidia/ml) was analyzed by regression analysis. 
supported our delimitation of the isolates of B. prunorum as new species, which is distantly related to isolates of $B$. cinerea. Therefore, our data reinforced the usefulness of the NEP gene analysis to separate closely related species within the genus Botrytis, as previously proposed (Oome and Van den Ackerveken 2014; Staats et al. 2007). On the basis of the phylogenetic analysis, B. prunorum was distantly related to the recently described Botrytis species on hosts other than Japanese plums, such as B. fabiopsis (Zhang et al. 2010a), B. sinoallii (Zhang et al. 2010b), B. pseudocinerea (Walker et al. 2011), B. caroliniana (Li et al. 2012), B. deweyae (GrantDownton et al. 2014), B. sinoviticola (Zhou et al. 2014), and Botrytis sp. B83 (Lorenzini and Zapparoli 2014).

Isolates of Botrytis from grapevines originally classified to group I (vacuma isolates) were characterized by the absence of the transposable elements Boty and Flipper (Fournier et al. 2005). The isolates in group I were recently described as a new cryptic species, B. pseudocinerea (Walker et al. 2011). In the present study, Flipper was not present in the tested isolates of both $B$. cinerea and B. prunorum, but Boty was present in some of the isolates of the two species, suggesting the presence or absence of the transposable element was irrelevant for the identification of $B$. prunorum.

NEP genes, first described on Fusarium oxysporum (Bailey 1995) and later on species of Botrytis (Oome and Van den Ackerveken 2014, Staats et al. 2007), encode necrosis and ethyleneinducing proteins and are considered virulence factors associated with the necrotrophic phase of certain pathogens (Mattinen et al. 2004). Therefore, the presence of the NEP genes in B. prunorum suggests that the interactions of this pathogen with the host share similar features with $B$. cinerea in terms of a necrotrophic lifestyle in at least part of the life cycle. It has been suggested that necrotrophic plant pathogens need to kill host tissue for nutrition (van Kan 2006).

In conclusion, Botrytis blossom blight is an annual threat to plum growers in Chile, and based on our results, a complex of at least two Botrytis species was found to be responsible for this disease on Japanese plums. These Botrytis species can be differentiated on the basis of PCR amplification and conidial production on APDA and PAM. B. cinerea was the predominant pathogen, and B. prunorum played a secondary role in the epidemiology of this disease on Japanese plums. Disease management strategies should take into account these pathogens.

\section{ACKNOWLEDGMENTS}

We thank J. J. Marois (University of Florida) for his suggestions and help in the editing of this manuscript, and G. A. Díaz (Universidad de Talca Chile), K. Elfar (Pontificia Universidad Católica de Chile), and L. Cottet (Universidad de Santiago, Chile) for their technical help during this project. We thank CONICYT for the doctorate scholarship given to the first author to pursue his postgraduate studies and for the financial support received through Project 7813110002 and to the grant received from "Tesis de la Industria," CONICYT project 781311002. We also thank DuPont Chile for the financial support provided to pursue this project.

\section{LITERATURE CITED}

Bailey, B. A. 1995. Purification of a protein from culture filtrates of Fusarium oxysporum that induces ethylene and necrosis in leaves of Erythroxylum coca. Phytopathology 85:1250-1255.

Castro, M., Kramer, K., Valdivia, L., Ortiz, S., and Castillo, A. 2003. A double-stranded RNA mycovirus confers hypovirulence-associated traits to Botrytis cinerea. FEMS Microbiol. Lett. 228:87-91.

Coley-Smith, J. R. 1980. Sclerotia and other structures in survival. Pages 85-114 in: The Biology of Botrytis. J. R. Coley-Smith, K. Verhoeff, and W. R. Jarvis, eds. Academic Press, United Kingdom.

Dahmen, H., Staub, T., and Schwinn, F. J. 1983. Technique for long-term preservation of phytopathogenic fungi in liquid nitrogen. Phytopathology 73:241-246.

Delaye, L., García-Guzmán, G., and Heil, M. 2013. Endophytes versus biotrophic and necrotrophic pathogens-are fungal lifestyles evolutionarily stable traits? Fungal Divers. 60:125-135.
Diolez, A., Marches, F., Fortini, D., and Brygoo, Y. 1995. Boty, a longterminal-repeat retroelement in the phytopathogenic fungus Botrytis cinerea. Appl. Environ. Microbiol. 61:103-108.

Droby, S., and Lichter, A. 2004. Post-Harvest Botrytis infection: Etiology, development and management. Pages 349-362 in: Botrytis: Biology, Pathology and Control. Y. Elad, B. Williamson, P. Tudzynski, and N. Delen, eds. Kluwer Academic Publishers, Netherlands.

Elmer, P. A., and Michailides, T. J. 2004. Epidemiology of Botrytis cinerea in orchard and vine crops. Pages 243-272 in: Botrytis: Biology, Pathology and Control. Y. Elad, B. Williamson, P. Tudzynski, and N. Delen, eds. Kluwer Academic Publishers, Netherlands.

Ferrada, E. E., Díaz, G. A., Zoffoli, J. P., and Latorre, B. A. 2015. First report of Botrytis cinerea causing blossom blight on Japanese plums in Chile. Plant Dis. 99:888.

Ferrada, E. E., Latorre, B. A., Díaz, G. A., and Zoffoli, J. P. 2014. Identification of Botrytis spp. causing blossom blight in Japanese plums and nectarines in Chile. (Abstr.) Phytopathology 104(suppl.):S3.40.

Flint, K. M. 1995. Green fruit rot. Pages 15-16 in: Compendium of Stone Fruit Diseases. J. Ogawa, E. Zehr, G. Bird, D. Ritchie, and J. Uyemoto, eds. The American Phytopathological Society, St. Paul, MN.

Fourie, J. F., and Holz, G. 1994. Infection of plum and nectarine flowers by Botrytis cinerea. Plant Pathol. 43:309-315.

Fournier, E., Giraud, T., Albertini, C., and Brygoo, Y. 2005. Partition of the Botrytis cinerea complex in France using multiple gene genealogies. Mycologia 97:1251-1267.

Grant-Downton, R. T., Terhem, R. B., Kapralov, M. V., Mehdi, S., and Rodríguez-Enríquez, M. J. 2014. A novel Botrytis species is associated with a newly emergent foliar disease in cultivated Hemerocallis. PLoS One 9:6.

Holz, G., Coertze, S., and Williamson, B. 2004. The ecology of Botrytis on plant surfaces. Pages 9-24 in: Botrytis: Biology, Pathology and Control. Y. Elad, B. Williamson, P. Tudzynski, and N. Delen, eds. Kluwer Academic Publishers, Netherlands.

Kurtzman, C. P., and Robnett, C. J. 1997. Identification of clinically important ascomycetous yeasts based on nucleotide divergence in the end of the largesubunit (26S) ribosomal DNA gene. J. Clin. Microbiol. 35:1216-1223.

Latorre, B. A., Elfar, K., and Ferrada, E. E. 2015. Gray mold (Botrytis cinerea), a limiting factor for grape production in Chile. Cien. Inv. Agric. 42: 305-330.

Levis, C., Fortini, D., and Brygoo, Y. 1997. Flipper, a mobile Fot1-like transposable element in Botrytis cinerea. Mol. Gen. Genet. 254:674-680.

Li, X. P., Kerrigan, J., Chai, W. X., and Schnabel, G. 2012. Botrytis caroliniana, a new species isolated from blackberry in South Carolina. Mycologia 104:650-658.

Lorenzini, M., and Zapparoli, G. 2014. An isolate morphologically and phylogenetically distinct from Botrytis cinerea obtained from withered grapes possibly represents a new species of Botrytis. Plant Pathol. 63:1326-1335.

Mattinen, L., Tshuikina, M., Mäe, A., and Pirhonen, M. 2004. Identification and characterization of Nip, necrosis-inducing virulence protein of Erwinia carotovora subsp. carotovora. Mol. Plant-Microbe Interact. 17:1366-1375.

Mirzaei, S., Goltapeh, E. M., Shams-Bakhsh, M., and Safaie, N. 2008. Identification of Botrytis spp. on plants grown in Iran. J. Phytopathol. 156:21-28.

Muñoz, G., Hinrichsen, P., Brygoo, Y., and Giraud, T. 2002. Genetic characterization of Botrytis cinerea populations in Chile. Mycol. Res. 106: 594-601.

Nuss, D. L. 2005. Hypovirulence: Mycoviruses at the fungal-plant interphase. Nat. Rev. Microbiol. 3:632-642.

O’Gorman, D. T., Sholberg, P. L., Stokes, S. C., and Ginns, J. 2008. DNA sequence analysis of herbarium specimens facilitates the revival of Botrytis mali, a postharvest pathogen of apple. Mycologia 100:227-235.

Ogawa, J. M., and English, H. 1960. Blossom blight and green fruit rot of almond, apricot and plum caused by Botrytis cinerea. Plant Dis. Rep. 44: 265-268.

Ogawa, J. M., Zehr, E. I., and Biggs, A. R. 1995. Brown rot. Pages 7-10 in: Compendium of Stone Fruit Diseases. J. Ogawa, E. Zehr, G. Bird, D. Ritchie, and J. Uyemoto, eds. The American Phytopathological Society, St. Paul, MN.

Oome, S., and Van den Ackerveken, G. 2014. Comparative and functional analysis of the widely occurring family of Nep1-like proteins. Mol. PlantMicrobe Interact. 27:1081-1094.

Pearson, M. N., and Bailey, A. M. 2013. Viruses of Botrytis. Adv. Virus Res. 86:249-272.

Potgieter, C., Castillo, A., Castro, M., Cottet, L., and Morales, A. 2013. A wild-type Botrytis cinerea strain co-infected by double-stranded RNA mycoviruses presents hypovirulence-associated traits. Virol. J. 10:220.

Staats, M., van Baarlen, P., Schouten, A., van Kan, J. A., and Bakker, F. T. 2007. Positive selection in phytotoxic protein-encoding genes of Botrytis species. Fungal Genet. Biol. 44:52-63.

Staats, M., van Baarlen, P., and van Kan, J. A. 2005. Molecular phylogeny of the plant pathogenic genus Botrytis and the evolution of host specificity. Mol. Biol. Evol. 22:333-346. 
Tamura, K., Petersen, D., Petersen, N., Stecher, G., Nei, M., and Kumar, S. 2011. Molecular evolutionary genetics analysis using maximum likelihood, evolutionary distance, and maximum parsimony methods. Mol. Biol. Evol. 28:2731-2739.

van Kan, J. A. L. 2006. Licensed to kill: The lifestyle of a necrotrophic plant pathogen. Trends Plant Sci. 11:247-253.

van Kan, J. A. L., Shaw, M. L., and Grant-Downton, R. T. 2014. Botrytis species: Relentless necrotrophic thugs or endophytes gone rogue? Mol. Plant Pathol. 15:957-961.

Walker, A. S., Gautier, A., Confais, J., Martinho, D., Viaud, M., Le Pêcheur, P., Dupont, J., and Fournier, E. 2011. Botrytis pseudocinerea, a new cryptic species causing gray mold in French vineyards in sympatry with Botrytis cinerea. Phytopathology 101:1433-1445.

White, T. J., Bruns, T., Lee, S., and Taylor, J. 1990. Amplification and direct sequencing of fungal ribosomal RNA genes for phylogenetics. Pages 315-322 in: PCR Protocols: A Guide to Methods and Applications. M. A.
Innis, D. H. Gelfand, J. J. Sninsky, and T. J. White, eds. Academic Press, New York.

Williamson, B., Tudzynski, B., Tudzynski, P., and van Kan, J. A. 2007. Botrytis cinerea: The cause of grey mold disease. Mol. Plant Pathol. 8: 561-580.

Zhang, J., Wu, M. D., Li, G. Q., Yang, L., Yu, L., Jiang, D. H., Huang, H. C., and Zhuang, W. Y. 2010a. Botrytis fabiopsis, a new species causing chocolate spot of broad bean in central China. Mycologia 102:1114-1126.

Zhang, L., Zhou, Y. J., Li, G. Q., Yang, L., Jiang, D. H., Zhuang, W. Y., and Huang, H. C. 2010b. Botrytis sinoallii, a new species of the gray mold pathogen on Allium crops in China. Mycoscience 51:421-431.

Zhou, Y. J., Zhang, J., Wang, X. D., Yang, L., Jiang, D. H., Li, G. Q., Hsiang, T., and Zhuang, W. Y. 2014. Morphological and phylogenetic identification of Botrytis sinoviticola, a novel cryptic species causing gray mold disease of table grapes (Vitis vinifera) in China. Mycologia 106:43-56. 